in existence. Parts of the collection already have been, or are in course of being, described, but accounts of special classes of exhibits are to be prepared and published from time to time. Among other notes in this issue of an interesting publication which is not so widely known as it deserves, is an account of the fragments of the unknown gospel acquired last summer, to which Mr. H. L. Bell has recently directed attention in The Times, and descriptions with illustrations of an Egyptian wax figure which, if it be, as is thought, a model for making moulds for casting bronze figures, is indeed rare, and some unique objects of a varied nature from Roman London.

\section{Empire Cotton Growing Corporation}

Ar a meeting of the Administrative Council of the Empire Cotton Growing Corporation held in Manchester on February 7, the resignation was received of Mr. Milligan, who has been the Corporation's senior representative in Africa since 1924. During this time he has travelled constantly about South Africa and visited in addition the Corporation's staff in Swaziland and Rhodesia. He has been succeeded by Mr. Parnell, who has long been associated with the Corporation's work in South Africa. The Council received the report of Mr. May, assistant secretary of the Corporation, upon a tour he had recently made in East and South Africa, particularly with reference to developments in Tanganyika Territory. At many places in this territory, the Corporation's assistance will be used towards developing an interesting scheme, evolved by the Agricultural Department, for native holdings on which cotton will be grown in a system of mixed farming. Each family will be given the freehold of their holding, which will consist of 20 acres. Of these, 10 acres will be reserved for cattle grazing, and the remainder for the dwelling site and land for the cultivation of cotton and other crops. The natives will also be given instruction in the preparation and use of farmyard manure.

THe Mwanza area of Lake Province has hitherto produced about half the cotton grown in Tanganyika. The organisation of its seed supply is therefore a matter of importance, and with the help that is now being given by the Corporation it is hoped to put this on a satisfactory basis. The selection of the best strains will be carried out at the Experiment Station at Ukiriguru; these will then be multiplied in the special area that is being provided for the purpose, just across the arm of Lake Victoria known as Smith Sound. The seed from this area will be bulked on an island in the Lake, which makes an admirable isolated area where admixture of the strains can be prevented. The bulked seed will then be distributed in the following season throughout the Lake Province.

\section{Forest Research in the Malay States}

THE annual report of the Forest Research Branch, 1933 , is issued with the "Report on Forest Administration for the year 1933 of the Federated Malay States" (a Supplement of the F.M.S. Government Gazette, June 15, 1934. F.M.S. Government Press). Research, under which is included education, has made con. siderable progress in the Forest Department of the Federated Malay States, A Forest School has been started much on the lines of the Rangers' School at Dehra Dun, India, which has nearly half a century of good work behind it. The practical courses of the Malay School during the year under view included a forest reconnaissance in mountainous jungle in the State of Perak; it served the excellent purpose, among others, of acquainting the students with commercial tree forms not normally encountered in the lowland forests. An area of 2,400 acres of this hill forest in the Bubu reserve was explored and the enumeration work was conducted on more intensive lines than hitherto, both as regards composition of the crop and the possibility of commercial exploitation. This appears an excellent departure and the experience thus gained should be invaluable to all, whilst the work achieved will be of practical value. Research work is being carried on in sylviculture, where some interesting research work is being achieved, botanical, wood technology, timber testing, wood preservation and forest economy generally; while zoological, chemical and meteorological problems are being studied.

\section{The National Herbarium at Melbourne}

Thanks to the generosity of Sir MacPherson Robertson, a new building has just been completed in Melbourne for the housing of the National Herbarium collections, and the transfer of material is in progress. The building is a block, approximately $100 \mathrm{ft}$. by $80 \mathrm{ft}$., containing two floors. On the upper floor provision is made for the collections (numbering some 1,500,000 sheets) and for a library of more than 10,000 volumes. On the lower floor are a museum of economic botany, a laboratory, a lecture hall and the administrative offices. The construction is fire-proof throughout; all cabinets are of steel and the main door is guarded by fire-proof devices operating automatically when the temperature reaches a certain point. The collection was commenced about 1856 by the late Baron von Mueller, and it is intended to preserve the existing division into two sections (i) Australian and (ii) extra-Australian. The former is very complete and contains a number of type specimens. The room allotted to it is $60 \mathrm{ft}$. by $35 \mathrm{ft}$., allowing for 30 per cent expansion, or 55 per cent if further cabinets be installed. The extra-Australian section, which is already extensive and is continually growing by exchanges, will be housed in a room $80 \mathrm{ft}$. by $35 \mathrm{ft}$.

\section{Sounds made by Fishes in the East Indies}

In NATURE of November 17 (p. 769), we quoted an interesting account of sounds heard in the East Indies by Capt. P. Jansen. We have received a letter from Dr. J. D. F. Hardenberg, of the Laboratory for Investigation of the Sea, Batavia, with reference to this note. He states that the comparison of these noises with the sounds made by foghoms is quite correct. They remind one also of the sounds made by motor traffic on a busy thoroughfare when heard at a distance of about a hundred yards. The noises, however, do not proceed from the earth, but are 